\title{
Thermal sterilization affects the content of selected compounds in diets for laboratory animals
}

\author{
A. Tuśnio ${ }^{1,6}$, M. Taciak', M. Barszcz', J. Paradziej-kukowicz², I. Olędzka³, W. Wiczkowski, \\ M. Szumska ${ }^{5}$, B. Pastuszewska ${ }^{1}$ and J. Skomiał ${ }^{1}$ \\ ${ }^{1}$ The Kielanowski Institute of Animal Physiology and Nutrition, Polish Academy of Sciences, 05-110 Jabłonna, Poland \\ ${ }^{2}$ Tri-City Central Animal Laboratory - Research and Service Centre of the Medical University of Gdańsk, \\ Dębinki 1, 80-211 Gdańsk, Poland \\ ${ }^{3}$ Medical University of Gdańsk, Hallera 107, 80-416 Gdańsk, Poland \\ ${ }^{4}$ Institute of Animal Reproduction and Food Research, Polish Academy of Sciences, Tuwima 10, 10-784 Olsztyn, Poland \\ ${ }^{5}$ Medical University of Silesia, Jordana 19, 41-808 Zabrze Rokitnica, Poland
}

KEY WORDS: diets, autoclaving, macronutrients, vitamins, acrylamide, isoflavones

Received: 25 April 2014

Revised: 14 October 2014

Accepted: 28 November 2014

${ }^{6}$ Corresponding author: e-mail: a.tusnio@ifzz.pl

\begin{abstract}
Autoclaving is the current method of choice for sterilization of diets for specified-pathogen-free (SPF) laboratory animals, but this process may negatively affect the nutrient content (e.g., protein, vitamin) of the diets. Two natural-ingredient diets supplemented with either soyabean meal containing phytoestrogens (S) or with casein (C), and a commercial autoclavable (SN) diet, were autoclaved at $121^{\circ} \mathrm{C}$ for $20 \mathrm{~min}(\mathrm{~T} 1)$ or at $134^{\circ} \mathrm{C}$ for $10 \mathrm{~min}$ (T2). Chemical composition, selected water- and fat-soluble vitamins, and acrylamide were analysed in all non-autoclaved (TO) and autoclaved diets, whereas in S diets, oestrogenic isoflavones were also determined. Autoclaving affected most protein bound to NDF macronutrient contents only to a small degree, except those of NDF and N-NDF. The contents of NDF and N-NDF were increased by $\mathrm{T} 2$ and $\mathrm{T} 1$; the change was the largest in the $\mathrm{SN}$ and the smallest in the $\mathrm{C}$ diet. Losses of particular vitamins differed among the diets and treatments. Among the water-soluble vitamins, thiamine, riboflavin and pyridoxine were the least affected, whereas calcium pantothenate was lowered by T1 and T2. Among fat-soluble vitamins, vitamin $E$ was the most stable, while vitamins $A$ and $D$, the least stable, but even the highest vitamin losses did not exceed $50 \%$. The acrylamide concentration increased more in diets autoclaved at T2 than at $\mathrm{T} 1$ and in the $\mathrm{S}$ and $\mathrm{C}$ diets than in SN. Autoclaving the $\mathrm{S}$ diet increased the daidzin and genistin contents and slightly reduced the total isoflavone content. It is concluded that the effects of autoclaving different diets are not uniform, but longer autoclaving at a lower temperature (T1) is less detrimental than shorter treatment at a higher temperature (T2), mainly because of the smaller increase in the NDF and N-NDF contents and acrylamide concentration.
\end{abstract}

\section{Introduction}

Autoclaving is a convenient and preferentially chosen method for sterilizing diets for specifiedpathogen-free (SPF) laboratory animals. The effects of autoclaving depend on the temperature and duration of the process (Eggum, 1969; Ford, 1976), but the impact of autoclaving according to programmes employed recently in breeding units has not been determined. Over-processing, e.g., heating at an 
excessively high temperature and/or for a long time, lowers the content and availability of nutrients, particularly vitamins and protein, and leads to formation of harmful components through the Maillard reaction.

Commercial 'autoclavable' diets for SPF animals are supplemented with greater amounts of vitamins than diets for conventional animals to compensate for anticipated losses, but no recommendations on the necessary levels of supplementation have been strictly defined, so two- or even four-fold excesses are provided (ICLAS, 1987). Losses of particular vitamins in differently processed feeds are variable - in extruded feeds they may vary from 5\% for choline to $85 \%$ for vitamin C (Riaz et al., 2009). Attempts have been made to enhance their retention by the use of protective technologies and more stable chemical forms (Coelho, 2002).

Autoclave sterilization leads to the formation of significant amounts of acrylamide, a neurotoxic and carcinogenic product of the reaction between asparagine and reducing sugars. Formation of acrylamide depends on the presence of precursors, on the processing conditions (temperature, time, $\mathrm{pH}$ ), and on the nature of the feed matrix (Friedman, 2003). Acrylamide is an inexpedient dietary component that may confound the results of chronic carcinogenicity studies (Twaddle et al., 2004), therefore its concentration in differently autoclaved diets should be monitored.

Most of the natural-ingredient diets for laboratory animals contain soyabean meal as the source of protein. Recently, the use of soya in stock diets for laboratory animals has ceased to be recommended since soya is a rich source of oestrogenic isoflavones that affect the hormonal status not only of breeding animals, but also their progeny, and may distort the outcome of the experiments (Brown and Setchell, 2001; Thigpen et al., 2004). Commercial 'phytoestrogen-free' or 'low-phytoestrogen' diets are now being offered to breeders, but little information on their protein component is available. Protein sources of animal origin such as fish meal (Rao, 1997) or milk products (Pastuszewska et al., 2008) supplemented with amino acids have been proposed as substitutes for soyabean meal, but it appears that the nutritional effects of thermal sterilization of soya-free and soya-containing diets are different (Taciak et al., in press). Whereas phytoestrogens are generally considered heat stable, no data have been found on the effect of heat treatment corresponding to autoclaving on their total content or that of particular compounds. It has been assumed that the potential decrease of the phytoestrogen concentration due to autoclaving may diminish the unfavourable consequences of using soya-containing diets for laboratory animals. Since autoclaving according to programmes involving different heating temperatures and times may modify the content of bioactive substances, optimization of autoclaving parameters should take into account these effects in the standardization of diets for SPF animals as models in biomedical research.

The objective of this study was to assess the effects of the two most frequently used autoclaving programmes on the content of macronutrients, vitamins and minerals, and on the formation of acrylamide in two experimental diets containing either soyabean meal or casein (low-phytoestrogen diet), and in an autoclavable commercial diet. Isoflavones (phytoestrogens) in the non-autoclaved and autoclaved soya-containing diet were also analysed. The autoclaving programmes consisted of longer heating at a lower temperature $\left(20 \mathrm{~min}\right.$ at $\left.121^{\circ} \mathrm{C}\right)$ and shorter heating at a higher temperature $(10 \mathrm{~min}$ at $134^{\circ} \mathrm{C}$ ).

\section{Material and methods}

\section{Composition and processing of the diets}

Two experimental natural-ingredient diets containing either soyabean meal or casein as the main protein sources ( $\mathrm{S}$ and $\mathrm{C}$, respectively) were produced. The autoclavable SSNIFF 1324-3 diet produced by SSniff Spezialdiäten GmbH (2006) and not declared as low-phytoestrogen, was used as the control (SN) diet. According to producer, the SN diet contained grain and grain by-products, oil seed products, minerals, brewer's yeast, vegetable oils, vitamins and trace elements (The SSniff Catalogue, 2006). The composition of the experimental diets is shown in Table 1. The amounts of all vitamins except $\mathrm{E}$, folic acid and choline in the premix produced by DSM Nutritional Products (Mszczonów, Poland) were increased proportionally to losses approximated or found due to autoclaving in preliminary trials.

The experimental $\mathrm{S}$ and $\mathrm{C}$ diets in the form of $11 \mathrm{~mm}$ pellets were packed into autoclavable perforated $10 \mathrm{~kg}$ paper bags, each diet into 4 bags, and autoclaved in a STERIVAP SP HP 9612-2ED steam autoclave (BMT, Czech Republic). The SN autoclavable diet was autoclaved in the original bags. Two bags of each diet were autoclaved at $121^{\circ} \mathrm{C}$ for $20 \mathrm{~min}$ or at $134^{\circ} \mathrm{C}$ for $10 \mathrm{~min}$ (programme T1 and T2, respectively), followed by cooling and drying for $15 \mathrm{~min}$. One portion of each diet was not autoclaved (T0). The efficiency of sterilization was verified using the SPORAL A biological test. 
Table 1. Proximal ingredient composition of experimental diets, $\mathrm{g} \cdot \mathrm{kg}^{-1}$ air dry basis

\begin{tabular}{llc}
\hline Ingredient & $\mathrm{C}^{1}$ & \multicolumn{1}{c}{$\mathrm{S}^{2}$} \\
\hline Cereals $^{3}$ & 665.1 & 605.3 \\
Soyabean meal & - & 200.0 \\
Casein & 140.0 & 50.0 \\
Fibre preparation & 50.0 & - \\
Oil & 40.0 & 40.0 \\
Dried brewer yeast & 40.0 & 40.0 \\
Macrominerals $^{4}$ & 45.0 & 45.0 \\
Microminerals $^{\text {Vitamins }}$ & 5.0 & 5.0 \\
Amino acids $^{5}$ & 10.0 & 10.0 \\
\hline
\end{tabular}

${ }^{1}$ diet containing casein as a supplementary protein source; ${ }^{2}$ diet containing soyabean meal as a supplementary protein source; ${ }^{3}$ wheat and maize; ${ }^{4}$ dicalcium phosphate, calcium carbonate, sodium chloride; ${ }^{5}$ L-lysine, DL-methionine, L-threonine, L-tryptophan

\section{Analytical methods}

Nutrient contents. AOAC (2000) methods were used for determination of the chemical composition of the diets, including fibre fractions (ADF, NDF), N-NDF, starch and sugars.

Minerals. The concentrations of $\mathrm{Ca}, \mathrm{Mg}, \mathrm{K}, \mathrm{Na}$, $\mathrm{Fe}, \mathrm{Cu}, \mathrm{Zn}$ and $\mathrm{Mn}$ were determined in mineralized samples by flame (air-acetylene) atomic absorption spectrometry using an AA-6300 Atomic Absorption Spectrophotometer (SHIMADZU, Japan) according to the procedure described in the Atom Absorption Data Book (1988). Each element was assayed at a specific analytical wavelength (i.e. at the most intense band). Total phosphorous and phytic phosphorus contents were determined using AOAC (2000) methods.

Vitamins. The following water- and fat-soluble vitamins were determined: thiamine hydrochloride $\left(B_{1}\right)$, riboflavin hydrochloride $\left(B_{2}\right)$, pyridoxine hydrochloride $\left(\mathrm{B}_{6}\right)$, calcium pantothenate, ascorbic acid (C), folic acid, biotin, retinol (A), ergocalciferol (D), tocopherol (E) and phytomenadione $\left(\mathrm{K}_{1}\right)$.

The water-soluble vitamins were extracted by solid-phase extraction (SPE) with a BAKERBOND spe $^{\mathrm{TM}}$ Cyano $(\mathrm{CN})$ Disposable Extraction Column from J.T. Baker, and separated by micellar electrokinetic chromatography (MEKC) in a single run within $8 \mathrm{~min}$. An electrolyte solution consisting of $100 \mathrm{mM} \mathrm{H}_{3} \mathrm{BO}_{3}, 5 \mathrm{mM} \mathrm{Na}_{2} \mathrm{~B}_{4} \mathrm{O}_{7}$ and $30 \mathrm{mM}$ sodium dodecyl sulphate (SDS) was used. Separation was done using a fused silica capillary (Beckman Coulter, Fullerton, CA, USA) under a constant voltage of $17 \mathrm{kV}$. Detection was performed spectrophotometrically at $200 \mathrm{~nm}$. The analytical procedure was described by Olędzka et al. (2012).
The fat-soluble vitamins were extracted by liquid-liquid extraction (LLE) and determined simultaneously using microemulsion electrokinetic chromatography (MEEKC). Separations of vitamins in microemulsions were achieved using uncoated fused silica capillaries (Beckman Coulter, Fullerton, CA, USA) under a constant voltage of $12 \mathrm{kV}$. The vitamins were separated in order of decreasing hydrophobicity. The detailed procedure was developed by Olędzka et al. (2014).

Acrylamide. The acrylamide content was determined according to the modified method of Wang et al. (2008). The modifications of the clean-up phase involved the use of n-hexane as a defatting agent and a more extensive sample pre-treatment procedure using two SPE sorbents: Isolute Multimode and Oasis HLB. The HPLC-DAD analysis was performed on an Ultimate 3000 HPLC (Dionex, USA) apparatus using Alltima $\mathrm{C} 18,5 \mu \mathrm{m}$ as an analytical column. Acrylamide was detected at UV wavelength of $212 \mathrm{~nm}$.

Phytoestrogens. The following isoflavones (phytoestrogens) and their conjugates were determined in S diets: daidzin, daidzein, genistein, genistin, glycitein, glycitin, 6 "-O-malonyl- $\beta$-glucosides of daidzein (6-OMalGlu-daidzein), 6"-acetyl-glucosides of daidzein (6-OAcGlu-daidzein), 6"-O-malonyl$\beta$-glucosides of genistein (6-OMalGlu-genistein) and 6"-acetyl-glucosides of genistein (6-OAcGlu-genistein). The modified analytical method of Wocławek-Potocka et al. (2005) was used. Isoflavones were extracted from $0.15 \mathrm{~g}$ pulverized samples with $80 \%$ methanol, with the step comprising sonication (30 s), vortexing (30 s) and centrifugation (13200 $\mathrm{g}$ for $10 \mathrm{~min}$ ) being repeated five times. Supernatants were collected in $5 \mathrm{ml}$ and after centrifugation (13200 $\mathrm{g}$ for $20 \mathrm{~min}$ ) were directly submitted to HPLC. The analysis of isoflavones was performed using an HPLC-UV/Vis system (SHIMADZU, Japan) consisting of two pumps (LC-10 $\mathrm{AD}_{\mathrm{vP}}$ ), UV/Vis detector (SPD-10 A) set at $254 \mathrm{~nm}$, autosampler set to $5 \mu \mathrm{l}$ injection (SIL-10 $\mathrm{AD}_{\mathrm{vP}}$ ), column oven (CTO-10 $\mathrm{AS}_{\mathrm{VP}}$ ) and system controller $\left(\mathrm{SCL}-10 \mathrm{~A}_{\mathrm{vP}}\right)$. Isoflavones were separated on a C18 XBridge column $3 \mu \mathrm{m} 150 \times 2.1 \mathrm{~mm}$ (Waters, USA) at $45^{\circ} \mathrm{C}$, eluted in a two-phase gradient system by solvents A (water/formic acid, 94/6, v/v) and B (acetonitrile/formic acid, 94/6, v/v) with a flow rate of $0.2 \mathrm{ml} \cdot \mathrm{min}^{-1}$. The gradients were: $10 \%-25 \%-80 \%-10 \%-10 \% \mathrm{~B}$ at gradient time, $\mathrm{t}_{\mathrm{G}}=0-38-40-42-60 \mathrm{~min}$. Isoflavones were identified according to the retention time of respective external standards. 


\section{Statistical analysis}

The results of chemical and mineral composition, vitamin content and acrylamide concentration were subjected to two-factorial ANOVA, while the results of phytoestrogen concentrations, to one-way ANOVA. Differences among groups were evaluated using the Tukey post-hoc test.

\section{Results}

The contents of the main nutrients in non-autoclaved (T0) diets differed both between the commercial $\mathrm{SN}$ and the experimental $\mathrm{C}$ and $\mathrm{S}$ diets and also, to some extent, between diets $\mathrm{C}$ and $\mathrm{S}$ (Table 2). In general, the commercial diet contained significantly less protein, fat and starch, whereas the differences between the experimental diets were in the significantly greater content of starch, crude fibre and both fibre fractions in $\operatorname{diet} \mathrm{C}$ than in $\mathrm{S}$.

Autoclaving affected dry matter, protein, fat, sugars and the ADF fraction significantly, but to a small extent. The fat content was depressed from $4.1 \%$ to $3.4 \%$ and $3.1 \%$, but only in the $\mathrm{SN}$ diet ( $P=0.000$ for interaction). It considerably increased the NDF and N-NDF contents in all the diets (Table 2); the effect of autoclaving using the T1 programme (longer time at a lower temperature) was smaller than using T2. The NDF content in diets autoclaved at $\mathrm{T} 1$ increased more in diet $\mathrm{SN}$ (from $15.4 \%$ to $25.1 \%$ ) than in S (from $11.0 \%$ to $15.5 \%$ ) and in C (from $14.4 \%$ to $15.7 \%$ ). The effect of autoclaving according to $\mathrm{T} 2$ was also greater in diets $\mathrm{SN}$ and $\mathrm{S}$ than in C, raising the NDF content to $29.0 \%, 19.6 \%$ and $17.2 \%$, respectively. The N-NDF contents were similar in non-autoclaved diets and increased more by autoclaving at $\mathrm{T} 2$ than $\mathrm{T} 1$ and more in $\operatorname{diet} \mathrm{SN}$ and $\mathrm{S}$ than in C. Autoclaving did not affect ash and starch contents.
The mineral composition of the diets differed significantly, except for the Fe content (Table 3). The calcium and phosphorus contents were greater and the phytic phosphorus content was lower in diets $\mathrm{C}$ and $\mathrm{S}$ than in $\mathrm{SN}$. The potassium, magnesium and manganese contents were greater in diet $\mathrm{SN}$ than in diets $\mathrm{C}$ and $\mathrm{S}$, while the sodium, copper and zinc contents were the lowest in diet SN. Autoclaving did not affect mineral composition, except for the $\mathrm{Ca}$ and $\mathrm{P}$ contents, which were decreased by both treatments - but only in diets $\mathrm{S}$ and $\mathrm{C}$ (interaction significant for $\mathrm{P}$ ). The interaction also affected the phytic phosphorus and manganese contents.

Biotin and folic acid were not detected among water-soluble vitamins, except folic acid in S diet autoclaved at T1 (Table 4). The contents of all analysed water-soluble vitamins differed among the diets and were affected by autoclaving and interaction. The non-autoclaved $\mathrm{S}$ and $\mathrm{C}$ diets contained more thiamine, similar amounts of riboflavin, and slightly less pyridoxine, pantothenic and ascorbic acids than SN diet.

Autoclaving at $\mathrm{T} 1$ had the most destructive effect on pantothenic acid in diets $\mathrm{S}$ and $\mathrm{C}$ since it decreased by about $50 \%$, whereas in diet SN it was not affected. Autoclaving at T2 had a slightly greater depressing effect on pantothenic acid in diets $\mathrm{C}$ and SN than autoclaving at $\mathrm{T} 1$, whereas it resulted in an inexplicably high pantothenic acid content in diet S. The effects of autoclaving on other water-soluble vitamins were small and irregular since riboflavin and pyridoxine levels increased in diet S after T2, ascorbic acid increased after $\mathrm{T} 1$ in $\operatorname{diet} \mathrm{C}$ and after $\mathrm{T} 2$ in $\operatorname{diet} \mathrm{S}$.

The contents of fat-soluble vitamins also differed among the diets and were affected by autoclaving and interaction (Table 4). The non-autoclaved diets S and C contained more vitamin A, considerably less vitamin $\mathrm{E}$ and similar amounts of vitamin D and $\mathrm{K}$ as $\operatorname{diet} \mathrm{SN}$.

Table 2. Chemical composition of the non-autoclaved and autoclaved diets, \% air dry matter

\begin{tabular}{|c|c|c|c|c|c|c|c|c|c|c|c|c|c|}
\hline \multirow{2}{*}{ Nutrients } & \multicolumn{3}{|l|}{$\mathrm{C}^{1}$} & \multicolumn{3}{|l|}{$S^{2}$} & \multicolumn{3}{|l|}{$\mathrm{SN}^{3}$} & \multirow{2}{*}{ SEM } & \multicolumn{3}{|l|}{$P$} \\
\hline & $\mathrm{TO}^{4}$ & $\mathrm{~T} 1^{5}$ & $\mathrm{~T} 2^{6}$ & T0 & $\mathrm{T} 1$ & $\mathrm{~T} 2$ & T0 & T1 & $\mathrm{T} 2$ & & $D^{7}$ & $\mathrm{~T}^{8}$ & $\mathrm{D} \times \mathrm{T}$ \\
\hline Dry matter & 88.8 & 88.1 & 88.2 & 88.6 & 88.0 & 87.9 & 89.8 & 89.9 & 90.1 & 0.003 & 0.000 & 0.000 & 0.000 \\
\hline Crude protein & 22.9 & 22.0 & 22.4 & 23.4 & 23.3 & 23.4 & 20.7 & 21.1 & 22.0 & 0.024 & 0.000 & 0.013 & 0.000 \\
\hline Crude ash & 6.2 & 6.1 & 6.0 & 7.1 & 7.0 & 7.1 & 6.6 & 6.5 & 6.4 & 0.118 & 0.000 & 0.301 & 0.477 \\
\hline Ether extract & 5.7 & 5.7 & 5.5 & 5.4 & 6.0 & 5.9 & 4.1 & 3.4 & 3.1 & 0.042 & 0.000 & 0.000 & 0.000 \\
\hline Crude fibre & 5.4 & 5.3 & 5.6 & 2.5 & 3.5 & 2.8 & 4.9 & 4.7 & 5.1 & 0.213 & 0.000 & 0.124 & 0.050 \\
\hline ADF & 9.0 & 9.7 & 9.8 & 4.7 & 5.6 & 5.3 & 6.5 & 7.1 & 7.3 & 0.281 & 0.000 & 0.015 & 0.912 \\
\hline NDF & 14.4 & 15.7 & 17.2 & 11.0 & 15.5 & 19.6 & 15.4 & 25.1 & 29.0 & 0.681 & 0.000 & 0.000 & 0.000 \\
\hline N-NDF & 0.2 & 0.3 & 0.4 & 0.2 & 0.6 & 1.0 & 0.2 & 1.0 & 1.5 & 0.797 & 0.000 & 0.000 & 0.000 \\
\hline Starch & 41.7 & 41.8 & 39.7 & 37.9 & 37.1 & 35.7 & 33.3 & 34.9 & 34.0 & 1.333 & 0.000 & 0.085 & 0.338 \\
\hline Sugars & 3.7 & 3.4 & 4.7 & 5.0 & 3.9 & 4.7 & 5.5 & 4.4 & 5.0 & 0.088 & 0.000 & 0.000 & 0.000 \\
\hline
\end{tabular}

${ }^{1,2}$ see Table $1 ;{ }^{3}$ commercially available SSNIFF diet; ${ }^{4}$ non-autoclaved; 5 autoclaved at $121^{\circ} \mathrm{C}$ for 20 min; ${ }^{6}$ autoclaved at $134^{\circ} \mathrm{C}$ for 10 min;

${ }^{7}$ diet; ${ }^{8}$ temperature 
Table 3. Mineral composition of the non-autoclaved and autoclaved diets

\begin{tabular}{|c|c|c|c|c|c|c|c|c|c|c|c|c|c|}
\hline \multirow{2}{*}{ Minerals } & \multicolumn{3}{|l|}{$\mathrm{C}^{1}$} & \multicolumn{3}{|l|}{$\mathrm{S}^{2}$} & \multicolumn{3}{|l|}{$\mathrm{SN}^{3}$} & \multirow{2}{*}{ - SEM } & \multicolumn{3}{|l|}{$P$} \\
\hline & $\mathrm{TO}^{4}$ & $\mathrm{~T} 1^{5}$ & $\mathrm{~T} 2^{6}$ & T0 & $\mathrm{T} 1$ & $\mathrm{~T} 2$ & T0 & T1 & $\mathrm{T} 2$ & & $\overline{D^{7}}$ & $\mathrm{~T}^{8}$ & $\mathrm{D} \times \mathrm{T}$ \\
\hline Calcium, $\mathrm{g} \cdot \mathrm{kg}^{-1}$ & 16.4 & 14.4 & 14.8 & 14.9 & 14.0 & 13.6 & 10.4 & 10.3 & 10.4 & 0.420 & 0.000 & 0.012 & 0.114 \\
\hline$P, g \cdot k^{-1}$ & 10.1 & 9.4 & 9.4 & 10.1 & 9.7 & 9.8 & 7.0 & 7.1 & 7.1 & 0.009 & 0.000 & 0.000 & 0.006 \\
\hline Phytic $P, g \cdot k^{-1}$ & 2.3 & 2.4 & 2.4 & 2.8 & 2.6 & 2.6 & 2.4 & 2.9 & 2.9 & 0.062 & 0.000 & 0.071 & 0.001 \\
\hline Non-phytic/total P & 0.77 & 0.74 & 0.74 & 0.72 & 0.73 & 0.73 & 0.66 & 0.59 & 0.59 & - & - & - & - \\
\hline $\mathrm{K}, \mathrm{g} \cdot \mathrm{kg}^{-1}$ & 4.9 & 4.4 & 4.5 & 9.7 & 9.5 & 9.6 & 12.3 & 12.1 & 12.2 & 0.182 & 0.000 & 0.154 & 0.893 \\
\hline $\mathrm{Na}, \mathrm{g} \cdot \mathrm{kg}^{-1}$ & 2.6 & 2.8 & 2.8 & 3.6 & 3.1 & 3.0 & 2.5 & 2.9 & 2.6 & 0.194 & 0.009 & 0.829 & 0.321 \\
\hline $\mathrm{Mg}, \mathrm{g} \cdot \mathrm{kg}^{-1}$ & 1.5 & 1.4 & 1.4 & 1.9 & 1.9 & 1.9 & 3.0 & 2.8 & 2.8 & 0.072 & 0.000 & 0.142 & 0.878 \\
\hline $\mathrm{Fe}, \mathrm{g} \cdot \mathrm{kg}^{-1}$ & 0.29 & 0.29 & 0.29 & 0.30 & 0.30 & 0.30 & 0.31 & 0.31 & 0.29 & 0.012 & 0.502 & 0.769 & 0.730 \\
\hline $\mathrm{Cu}, \mathrm{ppm}$ & 20.1 & 17.6 & 20.9 & 22.1 & 22.5 & 21.8 & 14.2 & 13.5 & 13.9 & 1.404 & 0.000 & 0.621 & 0.682 \\
\hline Zn, ppm & 128 & 140 & 95 & 139 & 118 & 121 & 116 & 109 & 114 & 5.958 & 0.005 & 0.095 & 0.465 \\
\hline $\mathrm{Mn}, \mathrm{ppm}$ & 94 & 107 & 102 & 106 & 99 & 86 & 133 & 134 & 135 & 2.925 & 0.000 & 0.245 & 0.015 \\
\hline
\end{tabular}

1,2, see Table 1; $34,5,6,6,7,8$ see Table 2

Table 4. Vitamins content in the non-autoclaved and autoclaved diets, $\mu \mathrm{g} \cdot \mathrm{g}^{-1}$

\begin{tabular}{|c|c|c|c|c|c|c|c|c|c|c|c|c|c|}
\hline \multirow{2}{*}{ Vitamins } & \multicolumn{3}{|l|}{$S^{1}$} & \multicolumn{3}{|l|}{$\mathrm{C}^{2}$} & \multicolumn{3}{|l|}{$\mathrm{SN}^{3}$} & \multirow{2}{*}{ SEM } & \multicolumn{3}{|l|}{$P$} \\
\hline & $\mathrm{TO}^{4}$ & $\mathrm{~T} 1^{5}$ & $\mathrm{~T} 2^{6}$ & T0 & T1 & T2 & T0 & $\mathrm{T} 1$ & T2 & & $\mathrm{D}^{7}$ & $\mathrm{~T}^{8}$ & $\mathrm{D} \times \mathrm{T}$ \\
\hline \multicolumn{14}{|l|}{ Water soluble } \\
\hline $\mathrm{B}_{1}$ & 28.9 & 25.9 & 21.6 & 18.5 & 20.8 & 20.2 & 15.3 & 14.9 & 14.2 & 0.091 & 0.000 & 0.000 & 0.000 \\
\hline $\mathrm{B}_{2}$ & 13.3 & 12.4 & 15.8 & 11.6 & 14.3 & 12.6 & 12.2 & 10.4 & 10.1 & 0.008 & 0.000 & 0.000 & 0.000 \\
\hline $\mathrm{B}_{6}$ & 7.4 & 7.3 & 10.1 & 8.8 & 9.3 & 8.9 & 10.9 & 10.7 & 10.6 & 0.066 & 0.000 & 0.000 & 0.000 \\
\hline pantothenic acid & 23.3 & 12.7 & 24.4 & 22.7 & 11.6 & 10.1 & 25.7 & 25.4 & 23.1 & 0.071 & 0.000 & 0.000 & 0.000 \\
\hline folic acid & ND & 5.8 & ND & ND & ND & ND & ND & ND & ND & - & - & - & - \\
\hline ascorbic acid & 32.8 & 37.5 & 41.8 & 33.9 & 41.5 & 25.3 & 39.1 & 36.7 & 36.5 & 0.140 & 0.000 & 0.000 & 0.000 \\
\hline biotin & ND & ND & ND & ND & ND & ND & ND & ND & ND & - & - & - & - \\
\hline \multicolumn{14}{|l|}{ Fat soluble } \\
\hline A & 182.0 & 152.0 & 101.0 & 168.0 & 155.0 & 115.0 & 100.7 & 91.2 & 76.9 & 0.808 & 0.000 & 0.000 & 0.000 \\
\hline D & 34.2 & 24.8 & 25.5 & 35.8 & 25.4 & 20.6 & 38.0 & 25.4 & 26.7 & 0.458 & 0.000 & 0.000 & 0.000 \\
\hline$E$ & 89.0 & 76.5 & 75.5 & 76.5 & 76.0 & 76.0 & 146.8 & 130.1 & 123.0 & 0.404 & 0.000 & 0.000 & 0.000 \\
\hline $\mathrm{K}$ & 24.9 & 22.6 & 21.2 & 26.6 & 22.8 & 19.2 & 29.1 & 27.3 & 25.2 & 0.080 & 0.000 & 0.000 & 0.000 \\
\hline
\end{tabular}

1,2 see Table $1 ;{ }^{3,4,5,6,7,8}$ see Table 2; ND - not detected

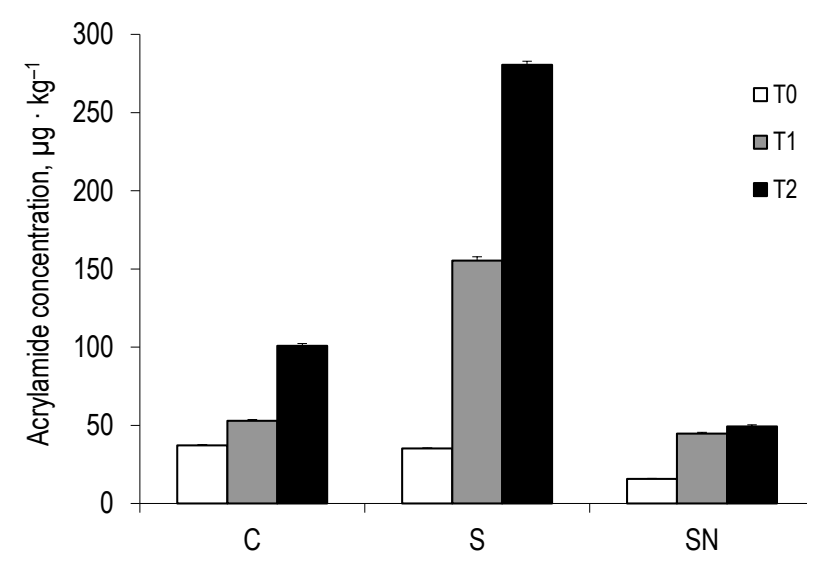

Figure 1. Acrylamide concentration in non-autoclaved and autoclaved diets, $\mu \mathrm{g} \cdot \mathrm{kg}^{-1}$. Effects of the experimental factors: $\operatorname{diet} P=0.000$; temperature $P=0.000$; interaction $P=0.000$; $C$ - diet with casein; $\mathrm{S}$ - diet with soyabean meal; SN - SNNIFF diet; T0 - non-autoclaved diets; $\mathrm{T} 1$ - diets autoclaved at $121^{\circ} \mathrm{C}$ for $20 \mathrm{~min} ; \mathrm{T} 2$ - diets autoclaved at $134^{\circ} \mathrm{C}$ for $10 \mathrm{~min}$
The contents of vitamins A and D were affected to the greatest extent by autoclaving. Programmes T1 and $\mathrm{T} 2$ progressively decreased the level of vitamin A (retention $55 \%, 68 \%$ and $76 \%$ in diets $\mathrm{S}, \mathrm{C}$ and $\mathrm{SN}$, respectively) and vitamin $\mathrm{D}$ (retention $57 \%, 70 \%$ and $74 \%$ in diets $\mathrm{C}$, SN and $\mathrm{S}$, respectively). The smallest losses were in vitamin $\mathrm{E}$ (retention from $85 \%$ to $99 \%$ in diets $\mathrm{S}$ and $\mathrm{C}$, respectively).

The acrylamide concentration was affected by diet, autoclaving and interaction (Figure 1). Among the non-autoclaved diets it was significantly greater in both experimental diets than in diet SN. Autoclaving significantly increased the acrylamide concentration in all diets, but to different extents. Autoclaving according to $\mathrm{T} 1$ increased acrylamide in diet $\mathrm{C}$ and $\mathrm{SN}$ to similar levels of 53 and $45 \mu \mathrm{g} \cdot \mathrm{kg}^{-1}$, respectively, and in HS diet to a higher level of $155 \mu \mathrm{g} \cdot \mathrm{kg}^{-1}$. Autoclaving at T2 practically did not increase the acrylamide concentration in diet $\mathrm{SN}$, whereas it raised it over $100 \mu \mathrm{g} \cdot \mathrm{kg}^{-1}$ in diet C and $280 \mu \mathrm{g} \cdot \mathrm{kg}^{-1}$ in $\mathrm{S}$. 
Table 5. Concentration of phytoestrogens in non-autoclaved and autoclaved soya-containing diet (S), $\mu \mathrm{M} \cdot \mathrm{g}^{-1}$

\begin{tabular}{llllll}
\hline Phytoestrogens & T0 & T1 & T2 & SEM & $P$ \\
\hline Daidzin & $0.25^{\mathrm{a}}$ & $0.31^{\mathrm{b}}$ & $0.28^{\mathrm{ab}}$ & 0.007 & 0.027 \\
Glycitin & 0.06 & 0.06 & 0.06 & 0.005 & 0.385 \\
Genistin & $0.40^{\mathrm{a}}$ & $0.49^{\mathrm{b}}$ & $0.43^{\mathrm{ab}}$ & 0.012 & 0.024 \\
6-OMalGlu-daidzein & 0.11 & 0.01 & 0.01 & - & - \\
6-OAcGlu-daidzein & 0.02 & 0.01 & - & - & - \\
6-OMalGlu-genistein & $0.21^{\mathrm{b}}$ & $0.07^{\mathrm{a}}$ & $0.06^{\mathrm{a}}$ & 0.003 & 0.000 \\
Daidzein & 0.01 & 0.02 & 0.02 & 0.003 & 0.192 \\
Glycitein & - & 0.01 & 0.01 & - & - \\
6-OAcGlu-genistein & 0.06 & 0.07 & 0.07 & 0.004 & 0.164 \\
Genistein & 0.01 & 0.02 & 0.02 & 0.004 & 0.649 \\
\hline
\end{tabular}

TO - non-autoclaved; T1 - autoclaved at $121^{\circ} \mathrm{C}$ for $20 \mathrm{~min}$; $\mathrm{T} 2$ - autoclaved at $134^{\circ} \mathrm{C}$ for $10 \mathrm{~min} ;{ }^{\mathrm{a}, \mathrm{b}}$ means within rows with different letters differ significantly at $P<0.05$

The effects of autoclaving on the concentration of phytoestrogenic isoflavones in diet $\mathrm{S}$ are presented in Table 5. The concentrations of the dominating compounds, daidzin and genistin, were significantly higher in diets autoclaved at T1 and T2 than in nonautoclaved diets. Autoclaving had the greatest effect on the concentration of 6-OMalGlu-genistein, which was significantly reduced from 0.21 to 0.07 and $0.06 \mu \mathrm{M} \cdot \mathrm{g}^{-1}$, respectively.

\section{Discussion}

The increase in the neutral detergent fibre (NDF) fraction and protein bound to NDF (N-NDF) in all diets was the most evident effect of autoclaving on macronutrients and is in line with the wellestablished effects of heat treatment on these parameters (Buraczewska et al., 1998). Both the NDF and $\mathrm{N}-\mathrm{NDF}$ contents were greater in diets autoclaved according to the $\mathrm{T} 2$ programme than the $\mathrm{T} 1$ programme, and the effect of autoclaving was considerably greater in diet SN than in diets $\mathrm{C}$ and S. Since the dietary NDF and N-NDF contents negatively affect the availability (ileal digestibility) of protein and amino acids in simple-stomached animals (Buraczewska et al., 1998; Gdala et al., 1998), it may be concluded that longer autoclaving at a lower temperature is less detrimental for protein value than shorter treatment at a higher temperature. This conclusion was confirmed by the results of Taciak et al. study (in press) on protein solubility and the nutritional value of autoclaved diets.

The content of particular minerals, such as $\mathrm{Ca}, \mathrm{K}, \mathrm{Cu}$ and $\mathrm{Mn}$, differed among the diets and autoclaving was found to affect the $\mathrm{Ca}$ and $\mathrm{P}$ contents. The absence of a significant effect of autoclaving on the phytic phosphorus content does not preclude the impact of heat treatment on phosphorus availability. The experimental diets contained wheat and, therefore, may be considered having high endogenous phytase activity, which could have been inactivated in autoclaved diets. Negative effects of pelleting wheat-containing diets at $80^{\circ} \mathrm{C}$ on phytase activity and phosphorus and calcium availability have been reported by Jongbloed and Kemme (1990).

The effects of autoclaving on the losses of water- and fat-soluble vitamins differed among individual vitamins, diets and treatments. In view of the lack of available data on the vitamin losses in autoclaved feeds, we compared our results with the effects of similar temperature ranges applied during extrusion and pelleting. Such comparisons are not, however, fully valid since physical factors such as screw speed, die diameter, or throughput also affect vitamin deterioration in differently processed feeds (Riaz et al., 2009).

Small losses (retention about $90 \%$ ) of riboflavin and pyridoxine in diets autoclaved at $121^{\circ} \mathrm{C}$ for 20 min agree with the values reported by Coelho (2002) for feeds extruded at a temperature of 116 to $120^{\circ} \mathrm{C}$ and are far smaller than losses in feeds pelleted at similar temperatures.

The substantially high stability of thiamine found in a recent study does not agree with the common knowledge on the sensitivity of this vitamin and with the results of a preliminary study of Taciak et al. (2011), who found far greater losses of $\mathrm{B}_{1}$ in an autoclaved vitamin premix. In Taciak et al. (2011), the retention of thiamine reached $73 \%$ only in a premix autoclaved at $105^{\circ} \mathrm{C}$ for 10 min, whereas it dropped to $15 \%$ and $17 \%$ in the premix autoclaved at $121^{\circ} \mathrm{C}$ for $20 \mathrm{~min}$ and $134^{\circ} \mathrm{C}$ for $10 \mathrm{~min}$, respectively. Also in a study reported by Riaz et al. (2009), the effect of temperature on thiamine stability seems to be greater than found in the recent study: high retention of thiamine in feed extruded at $91^{\circ} \mathrm{C}$ to $95^{\circ} \mathrm{C}$ declined to $50 \%$ when the temperature was raised the range of $141^{\circ} \mathrm{C}$ to $145^{\circ} \mathrm{C}$. According to data presented by Coelho (2002), the destructive effect of temperature on vitamin $\mathrm{B}_{1}$ depends on its chemical form and is greater on thiamine $\mathrm{HCl}$ than on thiamine mononitrate. It should be noted, however, that thiamine $\mathrm{HCl}$ was used in the experiment by Taciak et al. (2011) and in the recent experiment.

It may be concluded that whereas riboflavin and pyridoxine are relatively stable in diets autoclaved at lower $\left(121^{\circ} \mathrm{C}\right.$ for $\left.20 \mathrm{~min}\right)$ and higher temperatures $\left(134^{\circ} \mathrm{C}\right.$ for $\left.10 \mathrm{~min}\right)$, the stability of thiamine under these conditions seems equivocal and should be confirmed. 
The stability of calcium pantothenate in diets $\mathrm{S}$ and $\mathrm{C}$ found in our study was smaller than of $\mathrm{B}_{1}, \mathrm{~B}_{2}$ and $\mathrm{B}_{6}$. Retention at $\mathrm{T} 1$ was smaller than in feeds extruded at similar temperatures (Coelho, 2002), but comparable to feed pelleted at 116 to $120^{\circ} \mathrm{C}$.

In general, our recent results (Taciak et al., 2011) on the effects of autoclaving on vitamin $B_{1}$ and $\mathrm{Ca}$ pantothenate are inconsistent with the conclusions of Riaz et al. (2009), who designated vitamin $\mathrm{B}_{1}$ as sensitive and $\mathrm{Ca}$ pantothenate as heat stable during extrusion.

Contrary to expectations, vitamin $\mathrm{C}$ showed relatively high stability during autoclaving since it was depressed only in C diet autoclaved at T2. The high retention of vitamin $\mathrm{C}$ most probably may be due to the use of a stabilized form of this vitamin, since, according to Coelho (2002), its retention in extruded feeds may vary from $15 \%$ and $30 \%$ to $85 \%$ and $90 \%$, and in pelleted feeds from $15 \%$ to $85 \%$ (at comparable temperatures), depending on the chemical form and type of protection.

The failure to detect biotin and folic acid (except in one diet) may be the result of the detection limit being set too high in the method, as discussed by Olędzka et al. (2012). Both vitamins were added to the diets and their total destruction during pelleting does not seem probable. Folic acid showed high retention (near 90\%) when autoclaved according to the same programmes in the study by Taciak et al. (2011) and retention in the range from $70 \%$ to $77 \%$ in extruded and pelleted feeds (Coelho, 2002). Similar values have been reported for biotin.

Among the fat-soluble vitamins, vitamin E was the most stable under both autoclaving programmes. Also in the preliminary study of Taciak et al. (2011), vitamin E showed $100 \%$ retention under all parameters of autoclaving. According to Coelho (2002), retention of vitamin $\mathrm{E}$ in the form of an alcohol is very low, but in the acetate form, is about $90 \%$ and $84 \%$ in feeds extruded at the corresponding temperatures, and $84 \%$ in feed pelleted at a lower temperature $\left(116^{\circ} \mathrm{C}\right.$ to $\left.120^{\circ} \mathrm{C}\right)$. Opposite conclusions are presented by Riaz et al. (2009), who rank vitamin E itself, but also its complex form, as one of the most sensitive to the process of extrusion. This conclusion seems, however, questionable in view of the high retention of vitamin $\mathrm{E}$ even at elevated extrusion temperatures $\left(141^{\circ} \mathrm{C}\right.$ to $\left.145^{\circ} \mathrm{C}\right)$.

In all diets autoclaved according to $\mathrm{T} 1$, losses of vitamin A were smaller than when processed according to $\mathrm{T} 2$, and greater in diets $\mathrm{C}$ and $\mathrm{S}$ than in $\mathrm{SN}$. The differences among the diets might have been due to different forms of the supplement since the stability of vitamin A depends greatly on its form and protection. Taciak et al. (2011) found similar retention values for the same form of vitamin autoclaved according to the respective programmes. Greater losses were reported by Coelho (2002) in feeds extruded and pelleted at similar temperatures, and by Riaz et al. (2009) in feeds extruded and pelleted at lower temperatures.

Vitamin D was the least stable among the fatsoluble vitamins since, even at the lower autoclaving temperature, losses reached $30 \%$ and were greater than reported for extruded and pelleted feeds (Coelho, 2002).

The retention of vitamin $\mathrm{K}$ ranging from $72 \%$ to $86 \%$ was similar to that reported by Taciak et al. (2011) for this vitamin in a premix autoclaved under similar conditions. Far lower retention values, varying among chemical and protected forms from $35 \%$ to $50 \%$ and from $18 \%$ to $48 \%$, were reported for feeds extruded at temperatures similar to those in our study (Coelho, 2002). Also Riaz et al. (2009) documented losses of about $40 \%$ to $50 \%$ of vitamin $\mathrm{K}$ during pelleting and extrusion at lower temperatures.

In view of the reported discrepancies, further studies on the stability of vitamin K in feeds autoclaved according to different programmes are needed.

On general, the results of our study show that the heat stability of particular vitamins differs, but losses of the even the least heat-stable vitamins such as $\mathrm{A}$ and $\mathrm{D}$ do not exceed $50 \%$. It seems, therefore, that two-fold or greater supplementation of autoclavable diets is not necessary. Special attention should be paid to the choice of the most heat stable forms of supplemented vitamins.

Autoclaving had the most striking effects on the acrylamide concentration, differing greatly both among the diets and programmes. In the nonautoclaved diets, the acrylamide levels were higher in both the experimental $\mathrm{C}$ and $\mathrm{S}$ diets than in the $\mathrm{SN}$ diet (37.2, 35.3 and $15.8 \mu \mathrm{g} \cdot \mathrm{kg}^{-1}$, respectively). These values were close to the range of 3 to $22 \mathrm{ppb}$ reported by Twaddle et al. (2004) for 9 out of 10 commercial rodent diets produced by leading manufacturers and far lower than $130 \mathrm{ppb}$ reported for one diet.

A great number of multidisciplinary studies on acrylamide concern mainly its biochemistry, presence in food products and toxicity for humans based on animal tests (Friedman, 2003; Claus et al., 2008, Friedman and Levin, 2008). Since safe levels of acrylamide in rodent diets, as well as in heat-treated feeds for other animal species, have not been proposed, our results concerning the acrylamide contents in particular diets have only 
a comparative value indicating a smaller effect of longer autoclaving at a lower temperature than of shorter treatment at a higher temperature. On the other hand, ourstudy corroborates the conclusion of Twaddle et al. (2004) on the potential implications of autoclave sterilization of rodent diets used in toxicity studies.

Our results clearly indicate that there is an interaction between the composition of the diet and formation of acrylamide during processing, with the SN diet being the least, and the S diet, the most affected by autoclaving. Acrylamide is the product of the heat-induced reactions between the amino group of free asparagine and the carbonyl group of reducing sugars. The content of this compound in a feedstuff is the net result of formation and degradation, both processes being influenced by technology and substrates (Friedman, 2003; Rydberg et al., 2003; Claus et al., 2008; Adams et al., 2010). Model studies have shown that acrylamide formation increases with temperature from about $120^{\circ} \mathrm{C}$ to $170^{\circ} \mathrm{C}$, and then decreases (Friedman, 2003), whereas in dry cereal systems it reaches a maximum between $180^{\circ} \mathrm{C}$ and $200^{\circ} \mathrm{C}$ and declines at higher temperatures (Claus et al., 2008). The lower concentration of acrylamide in diets heated for $20 \mathrm{~min}$ at $121^{\circ} \mathrm{C}$ than for $10 \mathrm{~min}$ at $134^{\circ} \mathrm{C}$ is in agreement with the results of studies on the effect of baking time on acrylamide formation in bread, which showed that prolonged heating at a lower temperature effectively minimizes acrylamide formation. Generally, the increase of acrylamide in diets $\mathrm{C}$ and $\mathrm{S}$ due to autoclaving at $134^{\circ} \mathrm{C}$ as compared with $121^{\circ} \mathrm{C}$, is in agreement with the reported effects of temperature and time, whereas the large differences in the response of the three diets to autoclaving can be ascribed to dietary factors.

The primary factor affecting formation of acrylamide in a processed feed or food is the content of asparagine as the major precursor. The content of this amino acid is particularly elevated in potatoes, but it is also considerable in wheat (Claus et al., 2008), which may explain the relatively high level of acrylamide in the non-autoclaved, but previously pelleted, $\mathrm{C}$ and $\mathrm{S}$ diets. The explanation for the low level of acrylamide in the commercial SN diet is not possible since the detailed composition of the diet is not available. The lower levels of acrylamide in $\operatorname{diet} \mathrm{C}$ than in $\mathrm{S}$ may reflect an inhibitory effect of the concentrated protein of animal origin on the formation of acrylamide, as found by Rydberg et al. (2003) in potatoes supplemented with fish or meat. Those authors concluded that addition of these proteins produced a considerably greater decrease in the acrylamide content than would be expected in the case of a purely additive effect.
Also in an experiment with a cereal bakery product, the acrylamide content was reduced by about $50 \%$ when casein was added (after Claus et al., 2008).

In the present experiment, reduction of the acrylamide content was obtained by the addition of highly concentrated protein to heated products. The design of our study was different from the cited studies since we compared diets containing two different proteins, and the much higher acrylamide content in the soyabean meal diet may also have resulted from a stimulatory effect of the meal on acrylamide formation, due to a potentially greater asparagine content. We did not find any specific data on the asparagine content of soyabean meal, but the key role of this amino acid in the regulation of nitrogen metabolism in the soyabean plant and its high level in lentils (legumes) (Friedman, 2003) is suggestive.

Acrylamide is classified as 'probably carcinogenic for humans' and has numerous mutagenic, genotoxic and carcinogenic properties observed in laboratory animals (Twaddle et al., 2004; Erkekoglu and Baydar, 2010). A study performed in mice fed a diet containing $240 \mathrm{ppb}$ acrylamide demonstrated the bioavailability of the compound from the diet, its distribution to tissues and metabolic activation to a genotoxic metabolite (Twaddle et al., 2004). The authors conclude that diets sterilized by autoclaving are incompatible with studies on acrylamide carcinogenicity and neurotoxicity.

Our results show that both sterilization at a lower temperature and formulation of the diet are effective in lowering the acrylamide content. It can also be suggested that strategies and additives preventing acrylamide accumulation in food (Friedman and Levin, 2008) should be tested and employed in manufacturing autoclavable diets for laboratory animals.

The soyabean $(\mathrm{S})$ diet contained the main isoflavones with potential oestrogenic properties found in soyabean (Hall et al., 2005): trace amounts of aglycone forms of genistein, daidzein and glycitein, predominating $\beta$-glucosides of genistin and daidzin (and a small amount of glycitin), acetyl- $\beta$-glucosides and malonyl- $\beta$-glucosides of daidzein and genistein. Whereas the total amount of isoflavones tended to decrease due to autoclaving at $\mathrm{T} 1$ and $\mathrm{T} 2$ to $95 \%$ and $85 \%$ of their initial value, respectively, the concentrations of daidzin and genistin tended to increase. The greatest changes were found for malonyl genistein and daidzein glucosides, which decreased from 0.21 to 0.07 and from $0.11 \mu \mathrm{M} \cdot \mathrm{g}^{-1}$ to trace values, respectively. Our results seem to confirm the general statement of Cassidy (2005) that the variability of the isoflavone concentration and 
profile in soyabean products depends on many factors, including industrial processing. It is difficult to prove, but it seems doubtful that small modifications of the phytoestrogen contents and profile due to autoclaving may decrease the impact of soyacontaining diets on animal models and improve the acceptability of soyabean meal as a protein supplement in diets for laboratory animals.

\section{Conclusions}

The results of the present study show that longer autoclaving rodent diets at a lower temperature has a less destructive effect on vitamin A, leads to smaller modifications of fibre and protein-fibre fractions and formation of acrylamide than shorter autoclaving at a higher temperature. It is concluded that autoclaving at $121^{\circ} \mathrm{C}$ for $20 \mathrm{~min}$ may be considered preferable for sterilization of diets for specifiedpathogen-free rodents.

\section{Acknowledgements}

The present study was performed as a part of Project No. NR12 003506 'Development of nutritional and technological basis for production of diets for laboratory animals of high health and microbiological status', funded by the National Centre for Research and Development.

\section{References}

Adams A., Hamdani S., Van Lancker F., Mejri S., De Kimpe N., 2010. Stability of acrylamide in model systems and its reactivity with selected nucleophiles. Food Res. Int. 43, 1517-1522

AOAC, 2000. Association of Official Analytical Chemists, Official Methods of Analysis. $17^{\text {th }}$ Edition. Arlington, VA

Atom Absorption Data Book, 1988. Philips Scientific. Black Bear Press. Cambrige

Brown N.M., Setchell K.D.R., 2001. Animal models impacted by phytoestrogens in commercial chow: implications for pathways influenced by hormones. Lab. Invest. 81, 735-747

Buraczewska L., Gdala J., Wasilewko J., Buraczewski S., 1998. Ileal digestibily in pigs of protein and amino acids of heat treated rapeseed feeds as affected by protein associated with the NDF fraction. Oil Plants XIX, 175-186

Cassidy A., 2005. Dietary phyto-oestrogens: molecular mechanisms, bioavailability and importance to menopausal health. Nutr. Res. Rev. 18, 183-201

Claus A., Carle R., Schieber A., 2008. Acrylamide in cereal products. A review. J Cereal Sci. 47, 118-133

Coelho M., 2002. Vitamin stability in premixes and feeds. A practical approach in ruminant diets. In: Proceedings of $13^{\text {th }}$ Annual Florida Ruminant Nutrition Symposium, pp. 127-145

Eggum B.O., 1969. Der Einfluss der Sterilisation auf die Proteinqualität von Futtermischungen. Z. Tierphysiol. Tierernähr. Futtermittelk. 25, 204-210
Erkekoglu P., Baydar T., 2010. Toxicity of acrylamide and evaluation of its exposure in baby foods. Nutr. Res. Rev. 23, 323-333

Ford D.J., 1976. The effect of methods of sterilization on the nutritive value of protein in a commercial rat diet. Brit. J. Nutr. 35, 267-276

Friedman M., 2003. Chemistry, biochemistry, and safety of acrylamide. A review. J. Agr. Food Chem. 51, 4504-4526

Friedman M., Levin C.E., 2008. Review of methods for the reduction of dietary content and toxicity of acrylamide. J. Agr. Food Chem. $15,6113-6140$

Gdala J., Buraczewska L., Wasilewko J., 1998. Relationship between the NDF-protein content of legumes and ileal digestibility of protein and amino acids. In: Proceedings of $3^{\text {rd }}$ European Conference on Grain Legumes. Valladolid (Spain), pp. 384-385

Hall W., Rimbach G., Williams C.M., 2005. Isoflavones and endothelial function. Nutr. Res. Rev. 18, 130-144

ICLAS Guidelines on the Selection and Formulation of Diets for Animals in Biomedical Research, 1987. M.E. Coates (Editor). International Council for Laboratory Animals, Institute of Biology, London

Jongbloed A.W., Kemme P.A., 1990. Effect of pelleting mixed feeds on phytase activity and the apparent absorbability of phosphorus and calcium in pigs. Anim. Feed Sci. Tech. 28, 233-242

Olędzka I., Kowalski P., Bałuch A., Bączek T., Paradziej-Łukowicz J., Taciak M., Pastuszewska B., 2014. Quantification of the level of fat-soluble vitamins in feed based on the novel microemulsion electrokinetic chromatography (MEEKC) method. J. Sci. Food Agric. 94, 544-551

Olędzka I., Kowalski P., Bączek T., Muszyńska-Furas B., Paradziej-Łukowicz J., Taciak M., Pastuszewska B., 2012. Determination of water soluble vitamins in laboratory animal feed by micellar electrokinetic chromatography. Anal. Lett. 45, 689-701

Pastuszewska B., Taciak M., Ochtabińska A., Tuśnio A., Misztal T., Romanowicz K., Morawski A., 2008. Nutritional value and physiological effects of soya-free diets fed to rats during growth and reproduction. J. Anim. Physiol. Anim. Nutr. 92, 63-74

Rao G.N., 1997. New nonpurified diet (NTP-2000) for rodents in the National Toxicology Program's Toxicology and Carcinogenesis Studies. J. Nutr. 127, 842S-846S

Riaz M.N., Asif M., Ali R., 2009. Stability of vitamins during extrusion. Crit. Rev. Food Sci. Nutr. 49, 361-368

Rydberg P., Eriksson S., Tareke E., Karlsson P., Ehrenberg L., Tornqvist M., 2003. Investigations on factors that influence the acrylamide content of heated foodstuffs. J. Agr. Food Chem. 51, 7012-7018

Taciak M., Skomiał J., Tuśnio A., Pastuszewska B., Kopowski J., 2011. Effect of thermal sterilization on the chosen vitamins retention in vitamin preparations. Paper presented at: Animal Metabolism Control by Nutrition. In: Proceedings of Animal Nutrition of the $40^{\text {th }}$ Scientific Session. Piechowice (Poland), pp. 110-111

Taciak M., Tuśnio A., Święch E., Barszcz M., Staśkiewicz Ł., Skomiał J., Paradziej-Łukowicz J., Pastuszewska B., 2014. Effects of autoclaving of soy-free and soy-containing diets for laboratory rats on protein and energy value determined in vivo and in vitro. J. Amer. Assoc. Lab. Anim. Sci. (in press)

The Ssniff Catalogue, 2006. Ssniff Spezialdiäten $\mathrm{GmbH}$

Thigpen J., Setchell K.D.R., Saunders H.E., Haseman J.K., Grant M.G., Forsythe D.B., 2004. Selecting the appropriate rodent diet for endocrine disruptor research and testing studies. ILAR J. 45, 401-416 
Twaddle N.C., Churchwell M.I., McDaniel L.P., Doerge D.R., 2004. Autoclave sterilization produces acrylamide in rodent diets: implications for toxicity testing. J. Agr. Food Chem. 52, 4344-4349

Wang H., Lee A.W.M., Shuang S., Choi M.M.F., 2008. SPE/HPLC/UV studies on acrylamide in deep-fried flour-based indigenous Chinese foods. Microchem. J. 89, 90-97
Wocławek-Potocka I., Bah M.M., Korzekwa A., Piskuła M.K., Wiczkowski W., Depta A., Skarżyński D.J., 2005. Soybeanderived phytoestrogens regulate prostaglandine secretion in endometrium during cattle estrus cycle and early pregnancy. Exp. Biol. Med. 230, 189-199 